\title{
Review Article \\ Aggregatibacter actinomycetemcomitans: The virulence factors and relation to persistence biofilm formation
}

\author{
Syakir Syahiran, Wan Rohani Wan Taib, Norzawani Jaffar \\ Faculty of Health Science, Gong Badak Campus, Universiti Sultan Zainal Abidin (UniSZA), Kuala Terengganu, Terengganu \\ Darul Iman, Malaysia
}

(Received: August $2020 \quad$ Revised: October $2020 \quad$ Accepted: November 2020)

Corresponding author: Norzawani Jaffar. Email:zawanijaffar@unisza.edu.my

\begin{abstract}
Periodontitis is an infectious and inflammatory condition that is associated with subgingival biofilms in toothsupporting tissues. Among the several hundred isolated organisms in the oral cavity, one of the most isolated bacteria from infected periodontal pockets are Aggregatibacter actinomycetemcomitans. It is a Gram-negative, facultative anaerobic bacillus that causes juvenile (localized aggressive periodontitis) and adolescent periodontal diseases. The development of biofilms is an essential factor in pathogenesis for A. actinomycetemcomitans. The early attachment of A. actinomycetemcomitans to abiotic surfaces relies on its protein-like fimbriae. This organism's ability to form tenacious biofilms can determine its survival and progression. $A$. actinomycetemcomitans, a pathogen not solely in periodontal but also involve in some systemic infections. This species has several virulence factors and genes that contribute to its oral cavity survival and, worst of all, cause bone resorption and tooth loss. Genetic diversity between the different A. actinomycetemcomitans isolates are great, and their ability to express and release virulence factors varies. In this review article, we discuss about the potential virulence factors and candidates genes for A. actinomycetemcomitans and their roles within periodontal disease by revealing their functional biology in facilitating attachment to oral surfaces, hindering protection of the host and causing inflammation and degradation of tissue.
\end{abstract}

Keywords: Periodontal disease; Aggregatibacter actinomycetemcomitans; biofilm; virulence factors; virulence genes

\section{INTRODUCTION}

$\mathrm{P}$ eriodontal disease is an inflammatory state of the teeth affecting gum and bone support. Global Burden of Disease Study (1) reported that half of the world's population (3.58 billion people) were affected by oral diseases, with dental caries being identified as the most prevalent condition. In 2016, severe periodontal disease was also the $11^{\text {th }}$ most prevalent disease worldwide. Among the several hundred species isolated in the oral cavity, Aggregatibacter actinomycetemcomitans is one of the most commonly isolated bacteria in infected periodontal pockets. A. Actinomycetemcomitans is a Gram-negative, nonmotile coccobacillus anaerobic bacterium that colonizes the oral cavity of humans and is often correlated with aggressive periodontitis (2). This bacterium is a member of the Pasteurellaceae and HACEK group among the pathogen community. $A$. Actinomycetemcomitans was first reported by Klinger in 1912, who named it as Bacterium actinomycetemcomitans and later was modified by Lieske into Bacterium comitans in 1921, and finally it was renamed as Actinobacilius actinomycetemcomitans by Topley and Wilson in 1929 (3). In 2006, it was reclassified as Aggregatibacter actinomycetemcomitans by Nørskov-Lauritsen and Kilian (4). The formation of biofilms represents significant virulence and pathogenesis factor for A. actinomycetemcomitans. The extracellular polymer matrix containing polysaccharides, proteins, and extracellular DNA (eDNA) help microbial cells in biofilms to be retained. This biological activity is exerted by the functional virulence factors and genes in $A$. actinomycetemcitans to promote settlement and invading the epithelial cell and thus forming a matured and tenacious biofilm on it. So, in this review, the background details and several virulence factors of A. actinomycetemcomitans and their functional genes involved will be elaborated.

\section{Periodontal Disease}

Periodontal disease is a common type of disease involving inflammatory tissue-supporting conditions, for example, oral microbial, dental plaque and alveolar bone. Periodontal disease occurs when oral bacterial biofilm disturbs the connective tissues surrounding and supporting the tooth. The action induces an inflammatory response that contributes to the breakdown of the binding tissue attachment to teeth, alveolar bone, and eventually causes tooth loss (5). Gum bleeding, swollen gums, irritation, and sometimes bad breath can be seen as the symptom. Loss of gum attachment to the tooth in its more severe form causes "pockets" and loosening of the teeth. Noteworthy, poor oral hygiene and tobacco use are the main causes of periodontal disease as well as granulomatous disorders, hematological, 
dermatological, neoplastic, and immunosuppression. Genetic, environmental factors are a number of other factors that contribute to the development of periodontal disease, including stress, age, medication, diabetes, and smoking.

Several studies have shown that through general inflammatory effects or direct metabolism of chemical mutagenic agents, certain oral microbiomes could induce systemic or chronic disorders. According to Haubek (6), widespread periodontal disease has been linked with diabetes, adverse outcomes of pregnancy, pulmonary disease, and stroke. Moreover, periodontal can cause systemic severe conditions like pneumonia (7) and cardiovascular disease (8). Additionally, severe bacterial infections could be the cause or agent of oral cancer, as a number of periodontal bacteria and large bacterial salivary counts are associated with oral squamous cell carcinoma (9).

\section{Role of $A$. actinomycetemcomitans in periodontal disease}

In 1975, A. actinomycetemcomitans was first reported in localized juvenile periodontitis, now known as localized aggressive periodontitis (LAP) as a potential periodontal pathogen. Most cross-sectional findings have since revealed $A$. actinomycetemcomitans in adolescents are closely associated with periodontal disease. Recent reports by Kawamoto et al.,. have shown that in periimplantitis and periodontitis, $A$. actinomycetemcomitans can promote osteoclast formation and bone loss by inducing the secretion of interleukin 6 (IL-6) from human gingival fibroblasts (HGFs). In addition, Interleukin 8 (10) and interferon-inducible protein-10 (11) that plays a major role in bone resorption are regulated to correspond with the level of periodontal inflammation in periodontal diseases.

\section{Biofilm formation of $A$. actinomycetemcomitans}

The initial adhesion of $A$. actinomycetemcomitans to abiotic surfaces depends on protein fimbriae (12), polysaccharides (13) and extracellular DNA (14). Bacterial biofilms are bacterial communities where microbial cells are bound to the substrate surrounded by an extracellular polymeric material matrix. Polymeric $\beta$-1,6-N-acetyl-D-glucosamine (PGA) is a significant component of the cell-surrounding matrix in these biofilms (13). In A. actinomycetemcomitans, PGA development is regulated by enzymes encoded in the pgaABCD operon, and PGA biosynthesis involves the expression of all four genes (14). This lifestyle of biofilm is the cause of most infections involving bacteria. In addition, bacterial cells in biofilms can effectively evade the host immune system, possibly via inhibition of engulfment of biofilm cells by phagocytes. This may be due to biofilm matrix polymers, which are of low immunogenicity and have the ability to mechanically shield the surface-exposed epitopes of bacterial cells in biofilms from being recognized by the host immune system.

Compared with their planktonic stage, bacteria in biofilms are distinguished by intense antimicrobial resistance. In addition, biofilm cells are actively monitoring their surroundings and adapting their properties dynamically to the prevailing environment. Therefore, when needed, bacteria will express their necessary genes. Expression of bacterial virulence genes, for example, is regulated by sensing changes in the levels of certain compounds, such as bacterial signaling molecules, host compounds, toxic oxidants, and iron (15). Particularly, the bacteria living in biofilms suggested been using cytokines to modulate gene expression and biofilm formation. Such a mechanism cannot be observed in the planktonic form of bacteria, which indicates that the genes react to cytokines are regulated in biofilm form (16). This mechanism is appropriate for the progressiveness of periodontal disease as an abundance of bacterial biofilms found in the oral cavity.

\section{A. actinomycetemcomitans serotypes and pathogenicity}

The serotypes of A. actinomycetemcomitans have already been investigated. There are several serotypes discovered. Seven serotypes have been identified so far, such as serotypes a, b, c, d, e, f, and g, leaving 3-8 \% non-serotypeable of clinical isolates (17) with more than one serotype in an individual's mouth. According to Umeda et al.,. (18), genome analysis of $A$. actinomycetemcomitans could be classified into two major groups of serotype-specific polysaccharide antigens: serotypes: a, d, e, and f, and serotypes $b$ and $c$, to further explain their virulence variations. Among these serotypes, the most prevalent in the oral cavity are serotypes $a, b$, and $c$ (3). Furthermore, serotype b is often associated with aggressive periodontitis in young people, but the virulence and toxicity were not found to be strictly following the serotype pattern (19). Each $A$. actinomycetemcomitans serotype comprises a unique phenotypic and genotypic feature, but little is known about core gene expression and its effects on the virulence potential (20).

\section{Virulence factors of $\boldsymbol{A}$. actinomycetemcomitans}

It is indicated that A. actinomycetemcomitans has many virulence factors contributing to their survival in the oral cavity and allow them to combat the defense mechanism of the host. $A$. Actinomycetemcomitans expression of virulence factors can be divided into three groups based on Umeda et al.,., (Table 1; 18) with its virulence genes (Table 2). 
Table 1: Virulence factors of $A$. actinomycetemcomitans.

\begin{tabular}{|c|c|}
\hline Groups & Virulence Factors \\
\hline $\begin{array}{c}\text { 1. Facilitating attachment } \\
\text { to oral } \\
\text { surfaces. }\end{array}$ & $\begin{array}{c}\text { - adhesions } \\
\text { - invasions } \\
\text { - antibiotic resistance }\end{array}$ \\
\hline $\begin{array}{c}\text { 2. Hindering the } \\
\text { protection of the } \\
\text { host. }\end{array}$ & $\begin{array}{c}\text { - leukotoxins } \\
\text { (CDT) }\end{array}$ \\
\hline $\begin{array}{c}\text { 3. Causing inflammation } \\
\text { and } \\
\text { degradation of tissue. }\end{array}$ & $\begin{array}{c}\text { - lipopolysaccharide } \\
\text { - heat-shock protein (HSP) }\end{array}$ \\
\hline
\end{tabular}

\section{Facilitating attachment to oral surfaces}

\section{A. Adhesions}

Bacterial adherence is the first step in invading cells. Adhesins are components of the bacterial cell surface that mediate bacterial adhesion to surfaces of eukaryotic cells by binding to eukaryotic surface receptors. Fimbriae helps A. actinomycetemcomitans to firmly attach to surfaces such as teeth and epithelial subgingival crevicular cells to form a dense biofilm (21). The first described $A$ actinomycetemcomitans protein found to be involved in essential adherence of the organism to epithelial cells was the autotransporter adhesin protein (Aae). A study carried out by Rose et al.,. exhibited the aae gene deletion from two different $A$. actinomycetemcomitans strains that was capable to minimize the ability of mutant strains to bind to epithelial cells as relative to wild species (WT). The outer membrane protein 100 (Omp100) of A. actinomycetemcomitans 's is referred to as surfaceexpressed for adhesin. The deletion of ompl00 gene from A. actinomycetemcomitans Y4 strain resulted in decreased mutant adhesion and efficacy of invasion (22). In contrast, A. actinomycetemcomitans EmaA directly binds to collagen and fibronectin (23). The elimination of this bacterial adhesin decreases the fivefold binding of A. actinomycetemcomitans knockout strain to the exposed collagen of the rabbit cardiac valve tissue relative to a wild bacterium (24).

\section{B. Invasions}

Following attachment, bacteria can invade the cells, which induce multiple effectors such as microfilament and microtubule (25). A. actinomycetemcomitan invasion is a rapid process involving opening of the cell surface. These invasions happen by indentations on the cell surface as well as in membrane ruffles (3). The cells of $A$. actinomycetemcomitans bind through adhesins to surface receptors on the gingival cells-transferring receptor. The epithelial cell membrane has been wrecked and damaged, causing the bacteria's invaginations and internalized in a membrane vesicle (26). When infiltrated into the cells, $A$. actinomycetemcomitans can avoid immune attack by controlling genes and proteins and live in the cytoplasm.

\section{Antibiotic resistance}

Antibiotic resistance is a crucial global issue. The evolution of microorganism resistance toward antibiotics lead to misuse and overuse of antibiotic administration resulting in elevating antibiotic concentration in the surrounding environment (27). When the released antibiotic leads to pathogenic antibiotic-resistance bacteria into the area, it will become worse. Tetracycline resistance gene, for example, was reported in water samples collected from wastewater treatment plants near U.S. swine production facilities (28). Following this, genes of antibiotic resistance will be spreading in the exposed microorganism. Such data suggest that $A$. actinomycetemcomitans resistant to antibiotics are on the rise and likely to be responsible for potential delays in care. This problem intrigues researchers to analyze and test other alternatives against oral pathogens.

\section{Hindering the protection of the host}

\section{A. Leukotoxins}

A. actinomycetemcomitans 's leukotoxin is one of the main virulence factors that can kill immune tissues in the host. It is a large protein-forming pore toxin that is secreted from the A. actinomycetemcomitans cell membrane. This belongs to the family of bacterial cytolysins repeats-in-toxin (RTX) (29). The toxin operon consists of four coding genes such as ltxA, ltxB, ltxC, and ltxD, and the promoter is upstream of these genes (30). Type I secretion process takes the toxin to the outer bacterial membrane (31). The outer membrane structure is affected by inner membrane protein, MorC for efficient transfer of the toxin (32). Leukotoxin is cell-specific as well as speciesspecific. The toxin binds to neutrophils, monocytes and a subset of lymphocytes and forms openings in the membranes of these target cells, destroying their ability to maintain osmotic homeostasis, leading to cell death (3).

\section{B. Cytolethal distending toxin (CDT)}

CDT is a protein with an immunosuppressive role in the cell cycle. The toxin is either secreted freely or associated with the membrane of the producing bacteria. Strains of A. actinomycetemcomitans commonly associated with localized aggressive periodontitis (LAP) possessing cdt operon (33). This toxin comprises three subunits: subunit $\mathrm{B}(\mathrm{cdtB})$ is the active toxic subunit; subunits cdtA and cdtC are the target cell binding subunits; while cdtC supports subunit B delivery to cells. Phosphatidylinositol3,4,5-triphosphate phosphatase activity (PIP3 phosphatase) is the function of the active subunit, cdtB (34) and exhibits DNase I activity (3). Cellbased cdtB targets are cell cycle arrest in G0/G1 and 
G2/M by destroying DNA (phosphatase activity of PIP3) in T cells, macrophages, Hep-2 cells, and many epithelial cells (34). In addition, CDT induces macrophage destruction by preventing phagocytic activity and altering the balance of cytokines. In this process, cytokine production levels (IL-1 $\beta$, IL-10, and IL-12) increase, nitric oxide production is modulated, and TNF- $\alpha$ levels do not differ throughout macrophage cells due to the presence of CDT (35).

\section{Causing inflammation and degradation of} tissue

\section{A. Lipopolysaccharide}

Lipopolysaccharide (LPS) is a major external membrane element of Gram-negative bacteria that stimulates innate immune cells to initiate inflammatory responses through Toll-like receptor 4 (TLR4) (36). The TLR4 stimulates two separate signaling pathways that are MyD88-dependent pathway (NF-kB activation) and MyD88-independent pathway A. actinomycetemcomitans lipopolysaccharide induces pro-inflammatory mediators like IL-1 $\beta,-6,-8$, and TNF- $\alpha$ (37) and is closely linked to the adverse effects of pregnancy (38). The highlight of A. actinomycetemcomitans LPS is hematogenic dissemination and its impact on the fetoplacental unit, which causes low birth weight (LBW) associated with periodontitis (39) Research by Offenbacher et al.,. (40) shows that $A$. actinomycetemcomitans in mothers with LBW is lower than healthy control mothers. $A$. actinomycetemcomitan LPS (AaLPS) is also associated with the destruction of connective tissue and alveolar bone loss in periodontal diseases (41).

\section{B. Heat Shock Proteins (HSPs)}

During periodontal infections, environmental changes cause A. actinomycetemcomitans to synthesize heat shock proteins (HSPs) (42). HSPs are a set of highly conserved proteins expressed in response to cell stress, including nutrient deprivation, and play a critical role in protein folding, intracellular protein trafficking, and denatured protein coping (43) A. actinomycetemcomitans can induce GroEL (chaperonin 60; HSP60), DnaK (HSP80), and HtpG (HSP90) proteins to protect cells from lethal effects during heat stress (44)

GroEL interacts with a small protein composed of $10-\mathrm{kDa}$ subunits (GroES) in $A$. actinomycetemcomitans. GroES and GroEL encoding genes were combined in the same process (42). Protein that is homologous to GroEL is osteolytic. GroEL was found to encourage the proliferation of epithelial periodontal ligament cells at concentrations ranging from 0.4 to $1.0 \mu / \mathrm{mL}$. Increased apical proliferation in the junctional epithelium contributes to the widening of periodontal spaces, thereby creating a larger space for the growth of bacteria. Thus, in the periodontal pocket, GroEL contributes to the survival of $A$. actinomycetemcomitans. On the other hand, it is shown that a higher concentration of GroEL $(10 \mu \mathrm{g}$ protein / $\mathrm{mL})$ has cytotoxic effects on epithelial cells. Therefore, based on the abundance of A. actinomycetemcomitans in different areas of the body, the results of this protein could be both increased proliferation and cell death (45).

Table 2: Virulence factors, properties, genes, and its functions

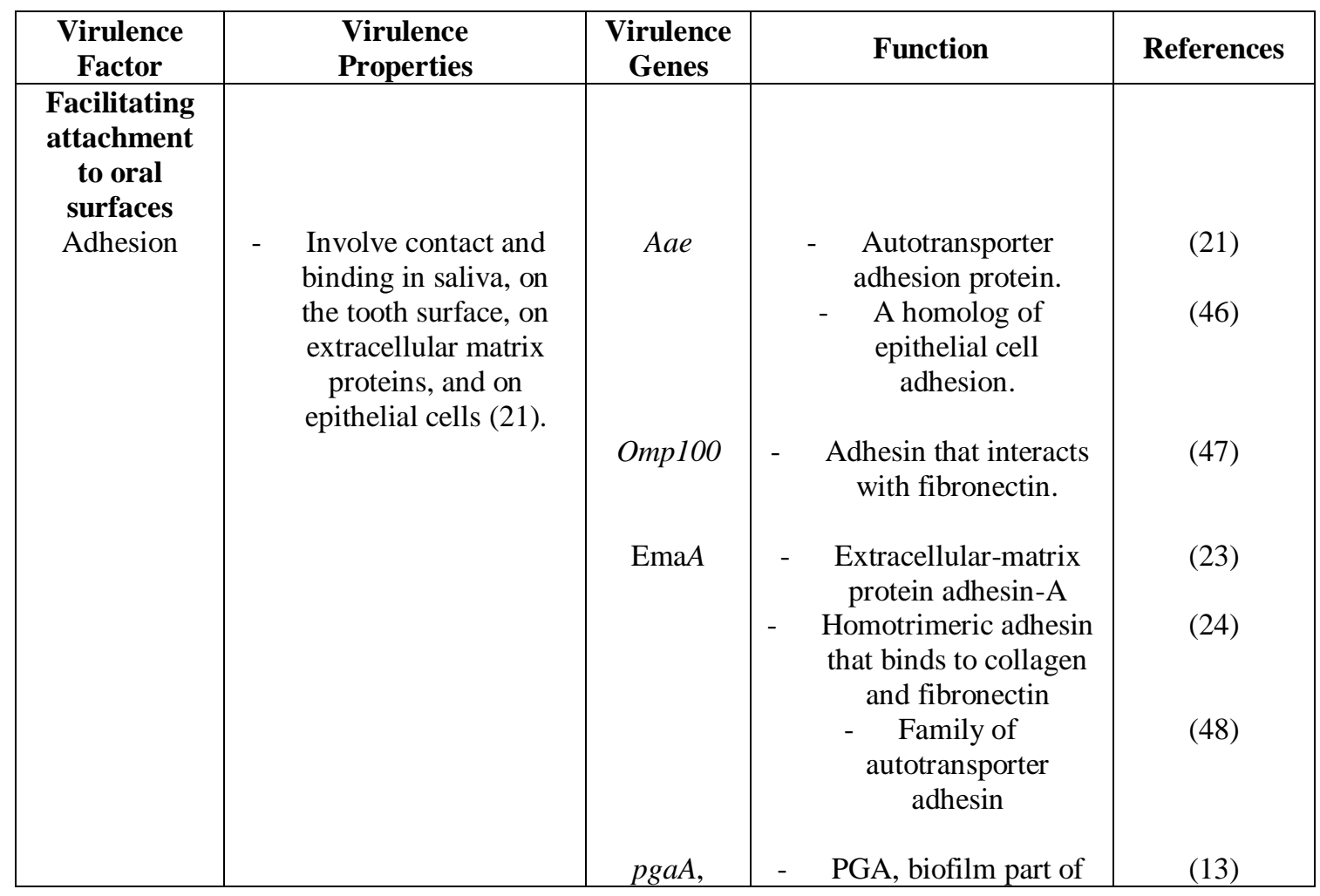




\begin{tabular}{|c|c|c|c|c|}
\hline & & $\begin{array}{l}\text { pgaB, } \\
\text { pgaC and } \\
\text { pgaD } \\
\text { flp-1 and } \\
\quad f l p-2 \\
\text { rcpA }\end{array}$ & $\begin{array}{l}\text { the cell-surrounding } \\
\text { matrix, internal } \\
\text { adhesion feature } \\
\text { Involve in the } \\
\text { development of the } \\
\text { major structural } \\
\text { element of fimbriae, } \\
\text { Flp1 protein. } \\
\text { Involve in the } \\
\text { formation of rough- } \\
\text { colony protein A- }- \\
\text { help fimbria attached } \\
\text { to host cells by } \\
\text { forming a channel }\end{array}$ & (49) \\
\hline Invasion & $\begin{array}{l}\text { - The cells of } A \text {. } \\
\text { actinomycetemcomitan } \\
s \text { bind through } \\
\text { adhesins, to surface } \\
\text { receptors on the } \\
\text { gingival cells- } \\
\text { transferring receptor. }\end{array}$ & Omp29 & $\begin{array}{c}\text { - } \begin{array}{c}\text { Expression of an } \\
\text { invasion-associated } \\
\text { enzyme }\end{array} \\
\text { - } \quad \text { The species increased } \\
\text { its expression of apaH } \\
\text { under anaerobic } \\
\text { conditions. } \\
\text { - } \quad \text { Increased capacity to } \\
\text { attack epithelial cells } \\
\text { under anaerobic } \\
\text { conditions. } \\
\text { Invasion of non- } \\
\text { phagocytic cells }\end{array}$ & (50) \\
\hline $\begin{array}{l}\text { Hindering } \\
\text { the } \\
\text { protection of } \\
\text { the host }\end{array}$ & & & & \\
\hline Leukotoxin & $\begin{array}{c}\text { - Proteinaceous toxin } \\
\text { secreted from the cell } \\
\text { membrane of } A \text {. } \\
\text { actinomycetemcomitan } \\
s \text {. } \\
\text { - The toxin attaches to } \\
\text { neutrophils, } \\
\text { monocytes, and a } \\
\text { subset of lymphocytes; } \\
\text { it forms pores in the } \\
\text { membranes that } \\
\text { overwhelm osmotic } \\
\text { homeostasis, leading to } \\
\text { cell death (3). }\end{array}$ & $\begin{array}{c}\operatorname{ltx} A, \operatorname{ltx} B, \\
\operatorname{ltx} C \text { and } \\
\operatorname{ltx} D\end{array}$ & $\begin{array}{l}\text { - } \quad \text { Ltx } A \text { codes the toxin's } \\
\text { structural protein. } \\
\text { - } \quad \text { Ltx } C \text { encodes post- } \\
\text { translational toxin } \\
\text { acylation components. } \\
\text { - LtxB and ltxD } \\
\text { encoding the toxin to } \\
\text { the outer membrane. }\end{array}$ & $\begin{array}{c}(30) \\
(3)\end{array}$ \\
\hline $\begin{array}{l}\text { Cytolethal } \\
\text { distending } \\
\text { toxin (CDT) }\end{array}$ & 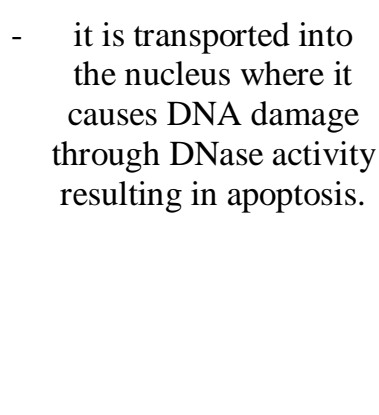 & $\begin{array}{l}\text { cdt - } \\
\text { cdtA, } \\
\text { cdtB and } \\
\text { cdtC }\end{array}$ & $\begin{array}{c}\text { Macrophage disrupts } \\
\text { by inhibiting } \\
\text { phagocytic activity } \\
\text { and influencing } \\
\text { interleukin production } \\
1-\beta, 6, \text { and } 8 . \\
\text { - The active toxic } \\
\text { subunit B (cdtB). } \\
\text { The cdtA and cdtC } \\
\text { subunits are the }\end{array}$ & $\begin{array}{l}(35) \\
(34)\end{array}$ \\
\hline
\end{tabular}




\begin{tabular}{|c|c|c|c|c|}
\hline $\begin{array}{c}\text { Causing } \\
\text { inflammation } \\
\text { and } \\
\text { degradation } \\
\text { of tissue }\end{array}$ & & & $\begin{array}{l}\text { subunits that bind } \\
\text { target cells. } \\
\text { - } \text { CdtC supports sub- } \\
\text { unit B distribution to } \\
\text { cells. }\end{array}$ & (45) \\
\hline $\begin{array}{c}\text { Heat-shock } \\
\text { proteins } \\
\text { (HSPs) }\end{array}$ & $\begin{array}{c}\text { - conserved proteins } \\
\text { expressed in response } \\
\text { to cell stress and play a } \\
\text { critical role in protein } \\
\text { folding, intracellular } \\
\text { protein trafficking and } \\
\text { denatured protein } \\
\text { coping (43). }\end{array}$ & $\begin{array}{l}\text { GroES } \\
\text { and } \\
\text { GroEL }\end{array}$ & $\begin{array}{c}\text { - } \quad \text { helps epithelial cell } \\
\text { propagation at lower } \\
\text { levels of HSP. } \\
\text { - } \quad \text { has a toxic effect on } \\
\text { epithelial cells at } \\
\text { higher levels of HSP. } \\
\text { - encourage the } \\
\text { proliferation of } \\
\text { epithelial periodontal } \\
\text { ligament cells }\end{array}$ & \\
\hline
\end{tabular}

\section{CONCLUSION}

The cytokines released in A. actinomycetemcomitans inflammation in periodontal disease are the leading cause of tissue destruction and bone resorption. New therapeutic approaches focused on $A$. actinomycetemcomitans virulence factors are expected to become part of standard clinical practice. Immunotherapies and inhibitors can be useful agents for preventing colonization of high burden or for treating infection. Although much additional work is required, it is already borne out the usefulness of targeting A. actinomycetemcomitans virulence factors.

\section{ACKNOWLEDGEMENT}

This study is part of the research funded by Fundamental Research Grants Scheme (FRGS) FRGS/1/2017/SKK06/UNISZA/02/1.

\section{CONFLICT OF INTEREST}

Authors declare no conflict of interest.

\section{REFERENCES}

1. Global Burden of Disease Study. Global, regional, and national incidence, prevalence, and years lived with disability for 328 diseases and injuries for 195 countries, 1990-2016: a systematic analysis for the Global Burden of Disease Study 2016; 2016; 390.

2. Faveri, M., Figueiredo, L. C., Duarte, P. M., Mestnik, M. J., Mayer, M. P. A., Feres, M. Microbiological profile of untreated subjects with localized aggressive periodontitis. J Clin Periodontol 2009; 36(9): 739-749.

3. Malik, R., Changela, R., Krishan, P., Gugnani, S., Bali, D. Virulence factors of Aggregatibacter actinomycetemcomitans - A status update. J Int Clin Dent Res Organ 2015; 7(2): 137-145.

4. Nørskov-Lauritsen, N. and Kilian, M. Reclassification of Actinobacillus actinomycetemcomitans, Haemophilus aphrophilus, Haemophilus paraphrophilus and Haemophilus segnis as Aggregatibacter actinomycetemcomitans gen. nov., comb. nov., Aggregatibacter aphrophilus comb. nov. and Aggregatibacter segnis comb. nov., and emended description of Aggregatibacter aphrophilus to include V factor-dependent and $\mathrm{V}$ factor-independent isolates. Int $\mathbf{J}$ Syst Evol Microbiol 2006; 56(Pt 9): 2135-2146.

5. Hernández, M., Dutzan, N., García-Sesnich, J., Abusleme, L., Dezerega, A., Silva, N. et al.,. Host-pathogen interactions in progressive chronic periodontitis. J Dent Res 2011; 90(10): 1164-1170.

6. Haubek, D. The highly leukotoxic JP2 clone of Aggregatibacter actinomycetemcomitans: evolutionary aspects, epidemiology and etiological role in aggressive periodontitis. APMIS Suppl. 2010; (130): 1-53.

7. Cagnani, A., Barros, A. Md. S., Sousa, L.L.A. de, Zanin, L., Bergamaschi, Cd. C., Peruzzo, D. C. et al., Periodontal disease as a risk factor for aspiration pneumonia: a systematic review. Biosci. J. 2016; 32(3):813-821.

8. Kholy, K. E., Genco, R. J., van Dyke, T. E. Oral infections and cardiovascular disease. Trends Endocrinol Metab 2015; 26(6): 315-321.

9. Mager, D. L., Haffajee, A. D., Devlin, P. M., Norris, C. M., Posner, M. R., Goodson, J. M. The salivary microbiota as a diagnostic indicator of oral cancer: a descriptive, nonrandomized study of cancer-free and oral squamous cell carcinoma subjects. J Transl Med. 2005; 3:27.

10. Kawamoto, D., Ando-Suguimoto, E. S., Bueno-Silva, B., DiRienzo, J. M., Mayer, M.P.A. Alteration of Homeostasis in Pre-osteoclasts Induced by Aggregatibacter actinomycetemcomitans CDT. Front Cell Infect Microbiol 2016; 6: 33.

11. Hosokawa, Y., Hosokawa, I., Shindo, S., Ozaki, K., Matsuo, T. Calcitriol Suppressed Inflammatory Reactions in IL-1 $\beta$ Stimulated Human Periodontal Ligament Cells. Inflammation. 2015; 38(6): 2252-2258.

12. Kachlany, S. C., Planet, P. J., Desalle, R., Fine, D. H., Figurski, D. H., Kaplan, J. B. flp-1, the first representative of a new pilin gene subfamily, is required for non-specific adherence of Actinobacillus actinomycetemcomitans. Mol Microbiol 2001; 40(3): 542-554.

13. Kaplan, J. B., Velliyagounder, K., Ragunath, C., Rohde, H., Mack, D., Knobloch, J.K.M., et al.,. Genes involved in the synthesis and degradation of matrix polysaccharide in Actinobacillus actinomycetemcomitans and Actinobacillus pleuropneumoniae biofilms. J Bacteriol 2004; 186(24): 8213-8220.

14. Izano, E. A., Sadovskaya, I., Wang, H., Vinogradov, E., Ragunath, C., Ramasubbu, N., et al.,. Poly-Nacetylglucosamine mediates biofilm formation and detergent resistance in Aggregatibacter actinomycetemcomitans. Microb Pathog. 2008; 44(1): 52-60. 
15. Dubbs, J. M., Mongkolsuk, S. Peroxide-sensing transcriptional regulators in bacteria. J Bacteriol 2012; 194(20): 5495-5503.

16. McLaughlin, R. A., Hoogewerf, A. J. Interleukin-1betainduced growth enhancement of Staphylococcus aureus occurs in biofilm but not planktonic cultures. Microb Pathog 2006; 41(2-3): 67-79.

17. Kaplan, J. B., Perry, M. B., MacLean, L. L., Furgang, D., Wilson, M. E., Fine, D. H. Structural and genetic analyses of $\mathrm{O}$ polysaccharide from Actinobacillus actinomycetemcomitans serotype f. Infect Immun 2001; 69(9): 5375-5384.

18. Umeda, J. E., Longo, P. L., Simionato, M.R.L., Mayer, M.P.A. Differential transcription of virulence genes in Aggregatibacter actinomycetemcomitans serotypes. J Oral Microbiol 2013; 5.

19. Haubek, D., Johansson, A. Pathogenicity of the highly leukotoxic JP2 clone of Aggregatibacter actinomycetemcomitans and its geographic dissemination and role in aggressive periodontitis. J Oral Microbiol 2014; 6.

20. Pinheiro, E. T., Kawamoto, D., Ota-Tsuzuki, C., Almeida, L.R.S., Nunes, A.C.R., Longo, P. L., et al., Analysis of genotypic variation in genes associated with virulence in Aggregatibacter actinomycetemcomitans clinical isolates. J Periodont Res 2011; 46(3): 310-317.

21. Rose, J. E., Meyer, D. H. and Fives-Taylor, P. M. Aae, an autotransporter involved in adhesion of Actinobacillus actinomycetemcomitans to epithelial cells. Infect Immun 2003; 71(5): 2384-2393.

22. Asakawa, R., Komatsuzawa, H., Kawai, T., Yamada, S., Goncalves, R. B., Izumi, S. et al.,. Outer membrane protein 100, a versatile virulence factor of Actinobacillus actinomycetemcomitans. Mol Microbiol 2003; 50(4): 11251139.

23. Ruiz, T., Lenox, C., Radermacher, M., Mintz, K. P. Novel surface structures are associated with the adhesion of Actinobacillus actinomycetemcomitans to collagen. Infect Immun 2006; 74(11): 6163-6170.

24. Tang, G., Kitten, T., Munro, C. L., Wellman, G. C., Mintz, K. P. EmaA, a potential virulence determinant of Aggregatibacter actinomycetemcomitans in infective endocarditis. Infect Immun 2008; 76(6): 2316-2324.

25. Yilmaz, O., Young, P. A., Lamont, R. J., Kenny, G. E. Gingival epithelial cell signalling and cytoskeletal responses to Porphyromonas gingivalis invasion. Microbiology (Reading, Engl ) 2003; 149(Pt 9): 2417-2426.

26. Lamont, R. J., Yilmaz, O. In or out: the invasiveness of oral bacteria. Periodontol 2000. 2002; 30(1): 61-69.

27. Kümmerer, K., Henninger, A. Promoting resistance by the emission of antibiotics from hospitals and households into effluent. Clin Microbiol Infect 2003; 9(12):1203-1214.

28. Auerbach, E. A., Seyfried, E. E., McMahon, K. D. Tetracycline resistance genes in activated sludge wastewater treatment plants. Water Res 2007; 41(5): 1143-1151.

29. Linhartová, I., Bumba, L., Mašín, J., Basler, M., Osička, R., Kamanová, J., et al., RTX proteins: a highly diverse family secreted by a common mechanism. FEMS Microbiol Rev 2010; 34(6): 1076-1112.

30. Henderson, B., Ward, J. M., Ready, D. Aggregatibacter (Actinobacillus) actinomycetemcomitans: a triple $\mathrm{A}^{*}$ periodontopathogen? Periodontol 2000 2010; 54(1): 78-105.

31. Kachlany, S.C. Aggregatibacter actinomycetemcomitans leukotoxin: from threat to therapy. J Dent Res 2010; 89(6): 561-570.

32. Gallant, C. V., Sedic, M., Chicoine, E. A., Ruiz, T., Mintz, K. P. Membrane morphology and leukotoxin secretion are associated with a novel membrane protein of Aggregatibacter actinomycetemcomitans. J Bacteriol 2008; 190(17): 5972-5980.

33. Tan, K. S., Song, K. P., Ong, G. Cytolethal distending toxin of Actinobacillus actinomycetemcomitans. Occurrence and association with periodontal disease. J Periodont Res 2002; 37(4): 268-272.

34. Smith, J. L., Bayles, D. O. The contribution of cytolethal distending toxin to bacterial pathogenesis. Crit Rev Microbiol. 2006; 32(4): 227-248.

35. Ando-Suguimoto, E. S., da Silva, M. P., Kawamoto, D., Chen, C., DiRienzo, J. M., Mayer, M.P.A. The cytolethal distending toxin of Aggregatibacter actinomycetemcomitans inhibits macrophage phagocytosis and subverts cytokine production. Cytokine. 2014; 66(1): 46-53.

36. Park, O. J., Cho, M. K., Yun, C. H., Han, S. H. Lipopolysaccharide of Aggregatibacter actinomycetemcomitans induces the expression of chemokines MCP-1, MIP-1 $\alpha$, and IP-10 via similar but distinct signaling pathways in murine macrophages. Immunobiology 2015; 220(9): 1067-1074.

37. Bodet, C., Chandad, F., Grenier, D. Anti-inflammatory activity of a high-molecular-weight cranberry fraction on macrophages stimulated by lipopolysaccharides from periodontopathogens. J Dent Res. 2006; 85(3): 235-239.

38. Newnham, J. P., Shub, A., Jobe, A. H., Bird, P. S., Ikegami, M., Nitsos, I., et al., The effects of intra-amniotic injection of periodontopathic lipopolysaccharides in sheep. Am J Obstet Gynecol. 2005; 193(2): 313-321.

39. Arce, R. M., Barros, S. P., Wacker, B., Peters, B., Moss, K., Offenbacher, S. Increased TLR4 expression in murine placentas after oral infection with periodontal pathogens. Placenta. 2009; 30(2): 156-162.

40. Offenbacher, S., Jared, H. L., O'Reilly, P. G., Wells, S. R., Salvi, G. E., Lawrence, H. P. et al., Potential pathogenic mechanisms of periodontitis associated pregnancy complications. Ann Periodontol 1998; 3(1): 233-250.

41. Kayal, R. A. The role of osteoimmunology in periodontal disease. Biomed Res Int 2013; 2013: 639368.

42. Goulhen, F., Grenier, D., Mayrand, D. Oral Microbial Heatshock Proteins and Their Potential Contributions to Infections. Critical Reviews in Oral Biology \& Medicine 2003; 14(6): 399-412.

43. Barreto, A., Gonzalez, J. M., Kabingu, E., Asea, A., Fiorentino, S. Stress-induced release of HSC70 from human tumors. Cellular Immunology. 2003; 222(2): 97-104.

44. Løkensgard, I., Bakken, V., Schenck, K. Heat shock response in Actinobacillus actinomycetemcomitans. FEMS Immunol Med Microbiol. 1994; 8(4): 321-328.

45. Goulhen, F., Grenier, D., Mayrand, D. Oral microbial heatshock proteins and their potential contributions to infections. Crit Rev Oral Biol Med. 2003; 14(6): 399-412.

46. Fink, D. L., Green, B. A., St. Geme, J. W. The Haemophilus influenzae Hap autotransporter binds to fibronectin, laminin, and collagen IV. Infect Immun. 2002; 70(9): 4902-4907.

47. Ouhara, K., Komatsuzawa, H., Shiba, H., Uchida, Y., Kawai, T., Sayama, K., et al., Actinobacillus actinomycetemcomitans outer membrane protein 100 triggers innate immunity and production of beta-defensin and the 18-kilodalton cationic antimicrobial protein through the fibronectin-integrin pathway in human gingival epithelial cells. Infect Immun. 2006; 74(9): 5211-5220.

48. Azari, F., Radermacher, M., Mintz, K. P., Ruiz, T. Correlation of the amino-acid sequence and the 3D structure of the functional domain of EmaA from Aggregatibacter actinomycetemcomitans. J Struct Biol. 2012; 177(2): 439446.

49. Smith, K. P., Ruiz, T. and Mintz, K. P. Inner-membrane protein MorC is involved in fimbriae production and biofilm formation in Aggregatibacter actinomycetemcomitans. Microbiology (Reading, Engl ) 2016; 162(3): 513-525.

50. Kajiya M., Komatsuzawa, H., Papantonakis, A., Seki, M., Makihira, S., Ouhara, K., et al., Aggregatibacter actinomycetemcomitans Omp29 is associated with bacterial entry to gingival epithelial cells by F-actin rearrangement. PLoS ONE 2011; 6(4): e18287. 